ORIGINAL ARTICLE

\title{
Cancer Rehabilitation Provided by Designated Cancer Hospitals in Japan: The Current State of Outpatient Setting and Coordination after Discharge
}

\author{
Takuya Fukushima, PT, PhD a Tetsuya Tsuji, MD, PhD ${ }^{\text {b }}$ Noriko Watanabe, PT a Takuro Sakurai, OT, PhD ${ }^{\text {a }}$ \\ Aiko Matsuoka, ST a Kazuhiro Kojima, ST, MSc a Sachiko Yahiro, OT a Mami Oki, OT a Yusuke Okita, PT, PhD ${ }^{a}$ \\ Shota Yokota, PT a Jiro Nakano, PT, PhD ${ }^{\mathrm{c}}$ Shinsuke Sugihara, MD, PhD ${ }^{\mathrm{d}}$ Hiroshi Sato, MD, PhD ${ }^{\mathrm{e}}$ \\ Juichi Kawakami, MD, PhD ${ }^{f}$ Hitoshi Kagaya, MD, PhD ${ }^{g}$ Akira Tanuma, MD, PhD ${ }^{\text {h }}$ Ryuichi Sekine, MD, PhD ${ }^{\mathrm{i}}$

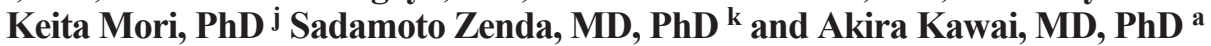

\begin{abstract}
Objectives: The aim of the present study was to clarify the current state of outpatient cancer rehabilitation and coordination systems provided by designated cancer hospitals in Japan. Methods: A questionnaire was sent to 427 designated cancer hospitals in Japan to investigate the status of outpatient cancer rehabilitation and whether it was sufficiently conducted. The status of regional coordination with post-discharge rehabilitation facilities was surveyed. Results: Responses were received from 235/427 facilities (55.0\%). Outpatient cancer rehabilitation was implemented in 92 (39.1\% of responding facilities), and of these facilities, $83.7 \%$ answered that the provision of rehabilitation was insufficient. The reasons were ineligibility for reimbursement of medical fees, a lack of human resources, a lack of awareness of the need, and a lack of education. Regional coordination was conducted by $39.1 \%$ of responding facilities, yet a regional alliance path had been established in only $9.8 \%$ of centers. The absence of coordination was associated with large facility size, the absence of physiatrists, and few rehabilitation professionals who had completed the training program; an insufficient framework for regional coordination was also given as a reason. Conclusions: To provide adequate outpatient cancer rehabilitation, sufficient human resources, the reimbursement of medical fees in the outpatient setting, and education and a framework to promote regional coordination are necessary.
\end{abstract}

Key Words: cancer rehabilitation; education; outpatient; regional alliance path; rehabilitation professionals

\section{INTRODUCTION}

Because of advances in early detection and treatment of patients with cancer, overall mortality has been declining since $1991 .^{1)}$ As a result, cancer survivorship after treatment continues to steadily increase. ${ }^{2-5)}$ However, as a result of treatment and the cancer itself, cancer survivors can develop various impairments and disabilities, such as cognitive dif-

Received: June 11, 2021, Accepted: January 17, 2022, Published online: February 10, 2022

${ }^{a}$ Department of Musculoskeletal Oncology and Rehabilitation, National Cancer Center Hospital, Tokyo, Japan

b Department of Rehabilitation Medicine, Keio University School of Medicine, Tokyo, Japan

${ }^{\mathrm{c}}$ Department of Physical Medicine and Rehabilitation, Kansai Medical University, Osaka, Japan

d Department of Orthopedic Oncology and Rehabilitation, National Hospital Organization Shikoku Cancer Center, Ehime, Japan

e Department of Gastroenterological Surgery, Saitama International Medical Center, Saitama Medical University, Saitama, Japan

${ }^{\mathrm{f}}$ Department of Rehabilitation Medicine, Shiga Prefectural Rehabilitation Center, Shiga, Japan

g Department of Rehabilitation Medicine I, School of Medicine, Fujita Health University, Aichi, Japan

${ }^{\mathrm{h}}$ Department of Rehabilitation Medicine, Juntendo University Shizuoka Hospital, Shizuoka, Japan

I Department of Pain and Palliative Care, Kameda Medical Center, Chiba, Japan

j Department of Clinical Research Center, Shizuoka Cancer Center, Shizuoka, Japan

${ }^{\mathrm{k}}$ Department of Radiation Oncology, National Cancer Center Hospital East, Chiba, Japan

Correspondence: Takuya Fukushima, PT, PhD, Department of Musculoskeletal Oncology and Rehabilitation, National Cancer Center

Hospital, 5-1-1 Tsukiji, Chuo-ku, Tokyo 104-0045, Japan, E-mail: takuyafukushima321@yahoo.co.jp

Copyright (C) 2022 The Japanese Association of Rehabilitation Medicine

This is an open-access article distributed under the terms of the Creative Commons Attribution Non-Commercial No Derivatives (CC BY-NC-ND) 4.0 License. http://creativecommons.org/licenses/by-nc-nd/4.0/ 
ficulties; motor palsy; muscle weakness; contracture; edema; and difficulties in swallowing, articulation, and excretion, ${ }^{6-8)}$ in addition to physical and mental symptoms, such as pain and fatigue. ${ }^{899}$ These dysfunctions remain in about half of cancer survivors more than 5 years after treatment, ${ }^{10)}$ resulting in impaired activities of daily living (ADL) $)^{8,11)}$ and reduced quality of life (QoL). ${ }^{12,13)}$ To avoid these disabilities, cancer rehabilitation before surgery, during chemotherapy and radiation therapy, and after treatment can improve muscle strength and aerobic fitness, ${ }^{14-16)}$ physical and psychological symptoms, ${ }^{15,17)}$ and QoL. ${ }^{18-20)}$

Japan's Cancer Control Act, enacted in 2006, guarantees that cancer patients receive rehabilitation appropriate to their needs. Introduced in 2007 to implement these directives, the Basic Plan to Promote Cancer Control Programs, Phase 1, prompted the development of a number of initiatives focused on cancer rehabilitation. ${ }^{21)}$ The Cancer Rehabilitation Educational Program for Rehabilitation teams (CAREER) was launched to train cancer rehabilitation specialists, and an educational system was established. Cancer rehabilitation in Japan is becoming more widespread and the implementation rate is increasing. ${ }^{22)}$ Although cancer rehabilitation has been officially recognized in Japan's healthcare insurance system as a new category of rehabilitation medicine, ${ }^{23)}$ only inpatient cancer rehabilitation is currently eligible for reimbursement. There is a concern, therefore, that the provision of post-discharge outpatient rehabilitation for cancer survivors is inadequate.

To inform the development of better rehabilitation frameworks for cancer patients, this study of cancer rehabilitation provided by designated cancer hospitals in Japan was conducted to gather basic data about the outpatient setting and the level of coordination with post-discharge facilities.

\section{MATERIALS AND METHODS}

\section{Study Design and Population}

This study implemented a questionnaire-based survey. The questionnaires were sent to rehabilitation professionals, including physical therapists, occupational therapists, speech and language therapists, and physiatrists, working at 427 designated cancer hospitals within Japan. The study was approved by the Research Ethics Committee of Japan's National Cancer Center (Ethics Committee Certificate No. 6000-019). Informed consent was obtained from all individual participants included in the study. Participants were considered to have provided informed consent by completing the questionnaire.

\section{Survey Method and Questionnaire}

In January 2020, a questionnaire was mailed to each eligible facility. Rehabilitation administrators at each facility were asked to complete the questionnaire by answering questions about the implementation status of outpatient cancer rehabilitation and regional coordination with post-discharge facilities after discharge. Table 1 gives the English translations of these questions, and the original Japanese version of the questionnaire is shown in Appendix 1.

\section{Statistical Analysis}

We calculated the frequencies of institutional characteristics (facility type, location, number of beds, presence of physiatrists, number of rehabilitation professionals), the implementation of outpatient cancer rehabilitation, and regional coordination with post-discharge facilities. Multivariate logistic regression analysis was carried out to identify the factors associated with implementation, inadequate outpatient cancer rehabilitation, and the absence of coordination involving rehabilitation professionals. The type of facilities (general hospital, all other hospitals), number of beds $(<600$, $\geq 600$ ), the presence of physiatrists (yes, no), the total number of rehabilitation professionals, and the number of rehabilitation professionals who had completed the CAREER program were entered as explanatory variables. Values of $\mathrm{P}<0.05$ were considered statistically significant. Data were analyzed using IBM SPSS Statistics version 27 software (IBM SPSS, Chicago, IL, USA).

\section{RESULTS}

We received responses from 235 facilities (response rate $55.0 \%)$. Among these, most were general hospitals $(\mathrm{n}=172$, $73.2 \%)$, followed by university hospitals $(\mathrm{n}=42,17.9 \%)$, cancer centers $(\mathrm{n}=15,6.4 \%)$, others $(\mathrm{n}=1,0.4 \%)$, and no answer $(n=5,2.1 \%)$. The characteristics of the facilities and rehabilitation staff are shown in Table 2.

Outpatient cancer rehabilitation was provided by 92 of the responding facilities (39.1\%). Among the implementing facilities, $77(83.7 \%)$ responded that the provision of outpatient cancer rehabilitation was inadequate (Table 3). In the multivariate analysis, no significant background factors related to the implementation or adequacy of outpatient cancer rehabilitation were extracted (Table 4). The reasons given for inadequate outpatient cancer rehabilitation included ineligibility for reimbursement of medical fees $(\mathrm{n}=60,77.9 \%)$ and lack of human resources $(\mathrm{n}=50,64.9 \%)$ (Table 3). Outpatient cancer rehabilitation was not implemented in 140 
Table 1. English version of the questionnaire

\begin{tabular}{|c|c|}
\hline Question & Choices \\
\hline \multicolumn{2}{|l|}{ 1. Facility overview } \\
\hline a. Type of facility & $\begin{array}{l}\text { - University hospital } \\
\text { - Cancer center } \\
\text { - General hospital } \\
\text { - Other }\end{array}$ \\
\hline b. Status of designated hospital & $\begin{array}{l}\text { - Prefecture designated cancer hospital } \\
\text { - Local designated cancer hospital } \\
\text { - Designated cancer hospital specializing in the } \\
\text { treatment of specific cancer types } \\
\text { - Local cancer hospital }\end{array}$ \\
\hline c. Location of facility & $\begin{array}{l}\text { - Hokkaido } \\
\text { - Tohoku } \\
\text { - Kanto } \\
\text { - Koushinetsu } \\
\text { - Hokuriku } \\
\text { - Tokai } \\
\text { - Kinki } \\
\text { - Chugoku } \\
\text { - Shikoku } \\
\text { - Kyushu and Okinawa }\end{array}$ \\
\hline d. Number of beds & $\begin{array}{l}\cdot<600 \\
\cdot \geq 600\end{array}$ \\
\hline e. Presence of physiatrists & $\begin{array}{l}-\mathrm{Yes} \\
\text { - No }\end{array}$ \\
\hline f. Number of rehabilitation professionals (PT, OT, ST) & Actual number \\
\hline $\begin{array}{l}\text { g. Number of rehabilitation professionals who have com- } \\
\text { pleted the CAREER program (PT, OT, ST) }\end{array}$ & Actual number \\
\hline
\end{tabular}

2. Implementation of cancer rehabilitation in the outpatient setting

a. Does your facility provide cancer rehabilitation in
the outpatient setting?
b. If 2 -a is "yes," is outpatient cancer rehabilitation
sufficiently implemented?
c. If 2-b is "insufficient," what are the reasons for insuf-
ficient cancer rehabilitation in the outpatient setting?

- Yes

- No

- Sufficient

- Insufficient

- Ineligible for reimbursement of medical fee

- Lack of education in outpatient cancer rehabilitation programs

- Shortage of rehabilitation professionals

- Eligible patients present but not prescribed

- Inadequate facilities and equipment

- Adherence is not achieved

- Others

(multiple answers allowed)

d. If 2-a is "no," what are the reasons for not implementing cancer rehabilitation in the inpatient

- Ineligible for reimbursement of medical fee

- Lack of human resources setting?

- Lack of education

- Lack of evidence

- No certainty of adherence

- Not knowing the specifics of the program

- No proof of efficacy in improving ADL and QOL 
Table 1. continued

Question

Choices

3. Status of the coordination systems involving rehabilitation professionals for patients with cancer

a. Does your facility have a coordination system involving rehabilitation professionals for patients with cancer?

b. If 3-a is "yes," does your facility have a regional alliance path involving rehabilitation professionals for patients with cancer?

c. If 3-a is "no," what are the reasons for difficulties in coordination?
- Yes

- No

- Yes

- No

- System is inadequate

- Large medical catchment area

- High degree of individuality of each patient

- No opportunity to introduce regional coordination

- Others

(multiple answers allowed)

Table 2. Breakdown of responding hospitals by institutional and rehabilitation staff characteristics

\begin{tabular}{|c|c|}
\hline \multicolumn{2}{|l|}{ Type of facility } \\
\hline University hospital & $42(17.9 \%)$ \\
\hline Cancer center & $15(6.4 \%)$ \\
\hline General hospital & $172(73.2 \%)$ \\
\hline Other & $1(0.4 \%)$ \\
\hline No answer & $5(2.1 \%)$ \\
\hline \multicolumn{2}{|l|}{ Status of designated hospital } \\
\hline Prefecture designated cancer hospital & $45(19.1 \%)$ \\
\hline Local designated cancer hospital & $145(61.7 \%)$ \\
\hline Designated cancer hospital specializing in the treatment of specific cancer types & $5(2.1 \%)$ \\
\hline Local cancer hospital & $21(8.9 \%)$ \\
\hline No answer & $19(8.1 \%)$ \\
\hline \multicolumn{2}{|l|}{ Location of facility } \\
\hline Hokkaido & $14(6.0 \%)$ \\
\hline Tohoku & $23(9.8 \%)$ \\
\hline Kanto & $58(24.7 \%)$ \\
\hline Koushinetsu & $16(6.8 \%)$ \\
\hline Hokuriku & $9(3.8 \%)$ \\
\hline Tokai & $18(7.7 \%)$ \\
\hline Kinki & $30(12.8 \%)$ \\
\hline Chugoku & $20(8.5 \%)$ \\
\hline Shikoku & $10(4.3 \%)$ \\
\hline Kyushu and Okinawa & $36(15.3 \%)$ \\
\hline No answer & $1(0.4 \%)$ \\
\hline \multicolumn{2}{|l|}{ Number of beds } \\
\hline$<600$ & $150(63.8 \%)$ \\
\hline$\geq 600$ & $84(35.8 \%)$ \\
\hline No answer & $1(0.4 \%)$ \\
\hline \multicolumn{2}{|l|}{ Presence of physiatrists } \\
\hline Yes & $116(49.4 \%)$ \\
\hline No & $117(49.8 \%)$ \\
\hline
\end{tabular}


Table 2. continued

\begin{tabular}{|c|c|}
\hline \multicolumn{2}{|c|}{$\begin{array}{l}\text { Number of rehabilitation professionals } \\
\text { PT }\end{array}$} \\
\hline$\leq 10$ & $53(22.6 \%)$ \\
\hline $11-20$ & $115(48.9 \%)$ \\
\hline $21-30$ & $38(16.2 \%)$ \\
\hline $31-40$ & $12(5.1 \%)$ \\
\hline$\geq 41$ & $16(6.8 \%)$ \\
\hline No answer & $1(0.4 \%)$ \\
\hline \multicolumn{2}{|l|}{ OT } \\
\hline$\leq 5$ & $90(38.3 \%)$ \\
\hline $6-10$ & $88(37.4 \%)$ \\
\hline $11-15$ & $34(14.5 \%)$ \\
\hline $16-20$ & $7(3.0 \%)$ \\
\hline$\geq 21$ & $12(5.1 \%)$ \\
\hline No answer & $4(1.7 \%)$ \\
\hline \multicolumn{2}{|l|}{ ST } \\
\hline$\leq 2$ & $65(27.7 \%)$ \\
\hline $3-4$ & $87(37.0 \%)$ \\
\hline $5-6$ & $41(17.4 \%)$ \\
\hline $7-8$ & $18(7.7 \%)$ \\
\hline$\geq 9$ & $19(8.1 \%)$ \\
\hline No answer & $5(2.1 \%)$ \\
\hline \multicolumn{2}{|c|}{ Number of rehabilitation professionals who had completed the CAREER program } \\
\hline$\leq 5$ & $62(26.4 \%)$ \\
\hline $6-10$ & $84(35.7 \%)$ \\
\hline $11-15$ & $52(22.1 \%)$ \\
\hline $16-20$ & $24(10.2 \%)$ \\
\hline$\geq 21$ & $11(4.7 \%)$ \\
\hline No answer & $2(0.9 \%)$ \\
\hline \multicolumn{2}{|l|}{ OT } \\
\hline$\leq 2$ & $71(30.2 \%)$ \\
\hline $3-4$ & $66(28.1 \%)$ \\
\hline $5-6$ & $51(21.7 \%)$ \\
\hline $7-8$ & $28(11.9 \%)$ \\
\hline$\geq 9$ & $12(5.1 \%)$ \\
\hline No answer & $7(3.0 \%)$ \\
\hline \multicolumn{2}{|l|}{ ST } \\
\hline$\leq 1$ & $70(29.8 \%)$ \\
\hline $2-3$ & $101(43.0 \%)$ \\
\hline $4-5$ & $36(15.3 \%)$ \\
\hline $6-7$ & $9(3.8 \%)$ \\
\hline$\geq 8$ & $3(1.3 \%)$ \\
\hline No answer & $16(6.8 \%)$ \\
\hline
\end{tabular}

CAREER, Cancer Rehabilitation Educational program for Rehabilitation teams; OT, occupational therapists; PT, physical therapists; ST, speech and language therapists.

facilities (59.6\%). Reasons for non-implementation included ineligibility for reimbursement of medical fees, lack of human resources, and insufficient education regarding outpatient cancer rehabilitation programs (Figure 1). Among the non-implementing facilities, 107 (76.4\%) perceived it as necessary.
Regional coordination involving rehabilitation professionals was implemented in 92 facilities (39.1\%) (Table 3). Multivariate analysis revealed that a high number of beds (odds ratio, 4.286; 95\% confidence interval, 1.87-9.81, $\mathrm{P}=$ 0.001 ), the absence of physiatrists (odds ratio, 1.922; $95 \%$ confidence interval, $1.01-3.64, \mathrm{P}=0.045)$, and a small num- 
Table 3. Implementation status of outpatient cancer rehabilitation and coordination (for the 235 facilities that responded)

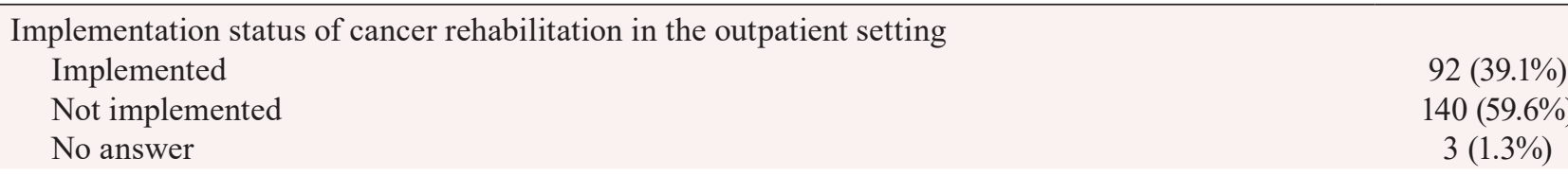

Is outpatient cancer rehabilitation sufficiently implemented?

(for the 92 facilities with outpatient cancer rehabilitation)

Sufficient

$15(16.3 \%)$

Insufficient

$77(83.7 \%)$

No answer

$0(0.0 \%)$

Reasons for insufficient cancer rehabilitation in the outpatient setting (multiple answers allowed)

Not eligible for reimbursement of medical fee

$60(77.9 \%)$

$15(19.5 \%)$

Lack of education in outpatient cancer rehabilitation programs

$50(64.9 \%)$

Lack of human resources

$20(26.0 \%)$

Eligible patients present but not prescribed

$4(5.2 \%)$

nadequate facilities and equipmen

$3(3.9 \%)$

Others

$8(10.4 \%)$

Existence of a coordination system involving rehabilitation professionals for patients with cancer

Yes

$92(39.1 \%)$

No

$135(57.4 \%)$

No answer

$8(3.4 \%)$

Existence of a regional alliance path involving rehabilitation professionals for patients with cancer

(for the 92 facilities with a regional alliance path)
Yes
$9(9.8 \%)$
No
$81(88.0 \%)$
No answer
$2(2.2 \%)$
Reasons for difficulties in coordination (multiple answers allowed)
System is inadequate
$70(51.9 \%)$
Large medical catchment area
$34(25.2 \%)$
High degree of individuality of each patient
$40(29.6 \%)$
No opportunity to introduce regional cooperation
$38(28.1 \%)$
Others
$17(12.6 \%)$
No answer
$16(11.9 \%)$

Table 4. Multivariate analysis: factors potentially associated with implementation and inadequate outpatient cancer rehabilitation

\begin{tabular}{|c|c|c|c|c|c|c|}
\hline \multirow[t]{2}{*}{ Parameter (reference) } & \multicolumn{3}{|c|}{$\begin{array}{l}\text { Implementation of outpatient } \\
\text { cancer rehabilitation }\end{array}$} & \multicolumn{3}{|c|}{$\begin{array}{l}\text { Inadequate outpatient } \\
\text { cancer rehabilitation }\end{array}$} \\
\hline & OR & $95 \% \mathrm{CI}$ & P-value & OR & $95 \% \mathrm{CI}$ & P-value \\
\hline $\begin{array}{l}\text { Type of facility (general hospital) } \\
\text { All other hospitals }\end{array}$ & 1.39 & $0.67-2.86$ & 0.38 & 0.36 & $0.09-1.51$ & 0.16 \\
\hline $\begin{array}{l}\text { Number of beds ( }<600 \text { beds) } \\
\geq 600 \text { beds }\end{array}$ & 1.13 & $0.55-2.36$ & 0.74 & 3.04 & $0.56-16.5$ & 0.20 \\
\hline Physiatrists (absent) & 1.17 & $0.63-2.17$ & 0.62 & 0.59 & $0.14-2.39$ & 0.46 \\
\hline $\begin{array}{l}\text { Total number of rehabilitation staff, per } \\
\text { person }\end{array}$ & 1.00 & $0.99-1.02$ & 0.91 & 0.99 & $0.96-1.03$ & 0.71 \\
\hline $\begin{array}{l}\text { Number of rehabilitation professionals who } \\
\text { had completed the CAREER program, per } \\
\text { person }\end{array}$ & 1.02 & $0.98-1.06$ & 0.47 & 1.01 & $0.92-1.11$ & 0.83 \\
\hline
\end{tabular}

CI, confidence interval; OR, odds ratio. 

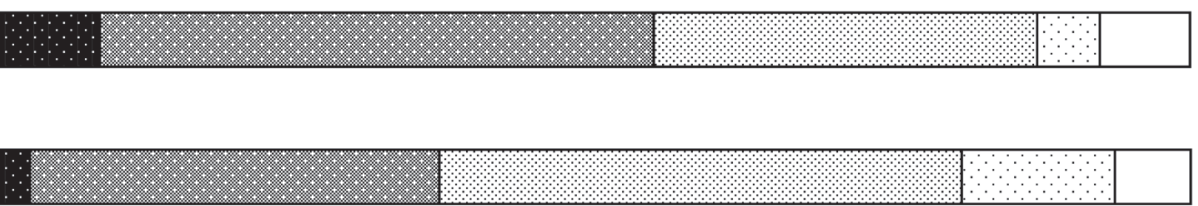

No certainty of adherence

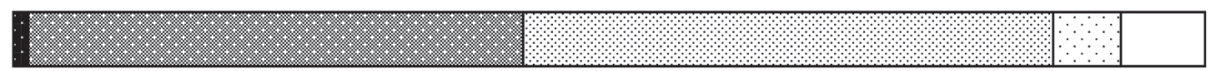

Not knowing the specifics of the program

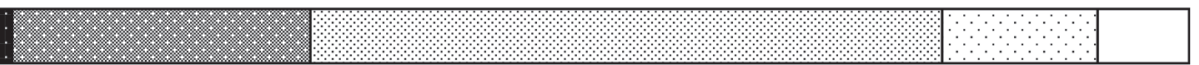

No proof of efficacy in improving ADL or QOL



Fig. 1. The reasons for non-provision of outpatient cancer rehabilitation.

Table 5. Multivariate analysis: predictor of non-coordination involving rehabilitation professionals

\begin{tabular}{|c|c|c|c|}
\hline \multirow[t]{2}{*}{ Parameter (reference) } & \multicolumn{3}{|c|}{$\begin{array}{l}\text { Predictors of non-coordination involving rehabilitation } \\
\text { professionals }\end{array}$} \\
\hline & OR & $95 \% \mathrm{CI}$ & P-value \\
\hline $\begin{array}{l}\text { Type of facility (general hospital) } \\
\text { All other hospitals }\end{array}$ & 0.59 & $0.27-1.29$ & 0.185 \\
\hline $\begin{array}{l}\text { Number of beds ( }<600 \text { beds) } \\
\geq 600 \text { beds }\end{array}$ & 4.29 & $1.87-9.81$ & 0.001 \\
\hline Absence of physiatrists & 1.92 & $1.01-3.64$ & 0.045 \\
\hline Total number of rehabilitation staff & 1.01 & $0.10-1.03$ & 0.165 \\
\hline $\begin{array}{l}\text { Number of rehabilitation professionals who had } \\
\text { completed the CAREER program }\end{array}$ & 0.95 & $0.91-1.00$ & 0.035 \\
\hline
\end{tabular}

ber of rehabilitation professionals who had completed the CAREER program (odds ratio, 0.954 ; 95\% confidence interval, 0.91-1.00, $\mathrm{P}=0.035$ ) were significant factors associated with not implementing regional coordination (Table 5). The main reason for non-implementation was the lack of a system for coordination, such as a regional alliance path (Table 3). A regional alliance path was in use at 9 facilities (9.8\%). Of the facilities that did not implement regional coordination, $96(64.0 \%)$ perceived the need for it.

\section{DISCUSSION}

In this study, we surveyed the current status of outpatient cancer rehabilitation and related systems for coordinating with post-discharge facilities at designated cancer hospitals in Japan. The results obtained should facilitate discussion on the efforts needed to further expand and improve outpatient cancer rehabilitation in Japan. 


\section{Outpatient Cancer Rehabilitation}

According to our survey findings, outpatient cancer rehabilitation was provided by less than $40 \%$ of designated cancer hospitals in Japan. Moreover, approximately 80\% of outpatient cancer rehabilitation providers regarded the provision of this service as insufficient. Although no background factors related to the implementation or sufficiency of outpatient cancer rehabilitation were extracted, a lack of human resources was cited as a reason for inadequacy, for which a contributing factor is the ineligibility for reimbursement of medical fees. The situation is similar to that reported overseas, and it has been pointed out that the lack of funds to adequately allocate rehabilitation professionals is a major factor in the inability to provide services. ${ }^{24)}$ The same reason was also cited by over three-quarters of facilities not providing outpatient rehabilitation. Insufficient human resources is a common problem that needs to be resolved regardless of whether outpatient rehabilitation is implemented. It is essential to make outpatient cancer rehabilitation eligible for reimbursement of medical fees to facilitate the engagement of more rehabilitation professionals in outpatient cancer rehabilitation.

Our survey also highlighted inadequate recognition within oncology units of the need for outpatient cancer rehabilitation and a lack of education concerning such programs as additional challenges to the provision of such services. To promote outpatient cancer rehabilitation, it is necessary to educate cancer patients and the medical staff in oncology departments about the necessity of cancer rehabilitation. The situation in Japan overlaps that seen in other countries, such as Canada and Australia, where a lack of cancer rehabilitation programs has been cited. ${ }^{25,26)}$ Professional training courses specific to rehabilitation are available in Japan in addition to the aforementioned CAREER program. However, in the current survey, the inadequate training of staff on outpatient cancer rehabilitation was cited as a factor for the inadequate provision or absence of services. In other words, it was suggested that strengthening these programs and educating staff are important issues.

The reasons for the non-provision of outpatient cancer rehabilitation given by respondents in this study were compared with the (unpublished) results of a similar survey conducted in 2016 as part of the Japan Agency for Medical Research and Development project, "Development of rehabilitation program for cancer patients in the outpatient setting." As in the 2016 survey, the present study cited the ineligibility for reimbursement of medical fees, a lack of human resources, a lack of education about the program, and insufficient evidence of the program's effectiveness, with little improvement in these factors over the 4 years. These issues should be addressed through continued efforts to support insurance payments covering expenses related to outpatient cancer rehabilitation, to educate staff about outpatient cancer rehabilitation, to reinforce training programs, and to conduct validation research to build evidence demonstrating the effectiveness of such services.

\section{Regional Coordination}

To improve the quality of care of cancer patients, it is important to provide rehabilitation without interruption before, during, and after treatment. For a smooth transition from inpatient to outpatient care, the integration of rehabilitation professionals in community partnerships can be an effective approach. Regional coordination involving rehabilitation was implemented in only about $40 \%$ of the facilities; therefore, the promotion of coordination must be prioritized in the field of cancer rehabilitation. Information sharing among community staff, facility staff, and patients/families through medical information sheets and conferences was cited by study participants. Furthermore, information sharing using the regional alliance path, a model for smooth mutual collaboration between facilities and the community, was also observed.

Hospitals with a high number of beds, a limited number of professionals who had completed the CAREER program, the absence of physiatrists, and poor coordination frameworks were identified as factors associated with the absence of coordination. First, in university hospitals and general hospitals with a high number of beds, the inclusion of a large catchment area and many patients from distant locations may make it difficult to coordinate care between facilities. The small number of professionals who had completed CAREER training and the absence of physiatrists indicate that there are few rehabilitation professionals who can judge the necessity of coordination, and this may have impeded regional coordination. Based on the result that small number of professionals who have completed CAREER program is associated with absence of coordination, the CAREER program, which aims to improve knowledge and skills related to cancer rehabilitation, is considered to have achieved a certain level of success. However, the CAREER program is currently only implemented for rehabilitation professionals working in hospitals. It is necessary to educate community-based rehabilitation professionals about cancer rehabilitation, and it is a challenge to facilitate the interactive coordination between medical care and the community. Our results show that the situation in Japan is similar to that 
in the United States, where there is a failure to coordinate outpatient cancer rehabilitation between cancer treatment centers and local providers, as well as poor recognition among cancer treatment specialists of the importance of cancer rehabilitation. ${ }^{24)}$ It is worth noting that about $60 \%$ of the facilities that did not coordinate with local medical institutions perceived the need for regional coordination. This finding suggests the need to proactively build a system of regional coordination to ensure the continuous follow-up of patients with a high need for cancer rehabilitation. Although the regional alliance path is considered an effective tool, less than $10 \%$ of facilities had an operational system in place. It is necessary to develop a method for screening patients who need cancer rehabilitation, ${ }^{24)}$ to provide information to patients and medical professionals, and to establish a system for coordination between facilities to enable the seamless and detailed implementation of rehabilitation interventions.

This study has a few limitations. First, because the effective response rate was moderate, this study may not accurately reflect the situation of all designated cancer hospitals in Japan. Second, as this study was conducted only in Japan, the results are likely to be influenced by factors relating to Japanese culture and the Japanese health care system. Therefore, it may be difficult to apply the results of this study directly to other countries.

\section{CONCLUSION}

In this study, the implementation rate of outpatient cancer rehabilitation and coordination was not high. To provide adequate outpatient cancer rehabilitation, sufficient human resources, the reimbursement of medical fees in the outpatient setting, and an educational framework to promote regional coordination are necessary.

\section{CONFLICTS OF INTEREST}

The authors declare that they have no conflicts of interest.

\section{REFERENCE}

1. Siegel RL, Miller KD, Jemal A: Cancer statistics, 2019. CA Cancer J Clin 2019;69:7-34. DOI:10.3322/ caac.21551, PMID:30620402

2. Miller KD, Nogueira L, Mariotto AB, Rowland JH, Yabroff KR, Alfano CM, Jemal A, Kramer JL, Siegel RL: Cancer treatment and survivorship statistics, 2019. CA Cancer J Clin 2019;69:363-385. DOI:10.3322/ caac.21565, PMID:31184787
3. Malvezzi M, Carioli G, Bertuccio P, Boffetta P, Levi F, La Vecchia C, Negri E: European cancer mortality predictions for the year 2019 with focus on breast cancer. Ann Oncol 2019;30:781-787. DOI:10.1093/annonc/ mdz051, PMID:30887043

4. Matsuda T, Ajiki W, Marugame T, Ioka A, Tsukuma H, Sobue T, Research Group of Population-Based Cancer Registries of Japan: Population-based survival of cancer patients diagnosed between 1993 and 1999 in Japan: a chronological and international comparative study. Jpn J Clin Oncol 2011;41:40-51. DOI:10.1093/ jjco/hyq167, PMID:20819833

5. Ito $\mathrm{Y}$, Miyashiro I, Ito $\mathrm{H}$, Hosono $\mathrm{S}$, Chihara $\mathrm{D}$, Nakata-Yamada K, Nakayama M, Matsuzaka M, Hattori M, Sugiyama H, Oze I, Tanaka R, Nomura E, Nishino Y, Matsuda T, Ioka A, Tsukuma H, Nakayama T, J-CANSIS Research Group: Long-term survival and conditional survival of cancer patients in Japan using population-based cancer registry data. Cancer Sci 2014;105:1480-1486. DOI:10.1111/cas.12525, PMID:25183551

6. Lange M, Joly F, Vardy J, Ahles T, Dubois M, Tron L, Winocur G, De Ruiter MB, Castel H: Cancer-related cognitive impairment: an update on state of the art, detection, and management strategies in cancer survivors. Ann Oncol 2019;30:1925-1940. DOI:10.1093/ annonc/mdz410, PMID:31617564

7. Christensen JF, Jones LW, Andersen JL, Daugaard G, Rorth M, Hojman P: Muscle dysfunction in cancer patients. Ann Oncol 2014;25:947-958. DOI:10.1093/ annonc/mdt551, PMID:24401927

8. Silver JK, Baima J, Mayer RS: Impairment-driven cancer rehabilitation: an essential component of quality care and survivorship. CA Cancer J Clin 2013;63:295317. DOI:10.3322/caac.21186, PMID:23856764

9. Dong ST, Butow PN, Costa DS, Lovell MR, Agar M: Symptom clusters in patients with advanced cancer: a systematic review of observational studies. J Pain Symptom Manage 2014;48:411-450. DOI:10.1016/j. jpainsymman.2013.10.027, PMID:24703941

10. Stubblefield MD, Schmitz KH, Ness KK: Physical functioning and rehabilitation for the cancer survivor. Semin Oncol 2013;40:784-795. DOI:10.1053/j.seminoncol.2013.09.008, PMID:24331197 
11. Neo J, Fettes L, Gao W, Higginson IJ, Maddocks M: Disability in activities of daily living among adults with cancer: a systematic review and meta-analysis. Cancer Treat Rev 2017;61:94-106. DOI:10.1016/j. ctrv.2017.10.006, PMID:29125982

12. Omran S, Mcmillan S: Symptom severity, anxiety, depression, self-efficacy and quality of life in patients with cancer. Asian Pac J Cancer Prev 2018;19:365-374. DOI:10.22034/APJCP.2018.19.2.365, PMID:29479979

13. Silver JK, Baima J: Cancer prehabilitation: an opportunity to decrease treatment-related morbidity, increase cancer treatment options, and improve physical and psychological health outcomes. Am J Phys Med Rehabil 2013;92:715-727. DOI:10.1097/ PHM.0b013e31829b4afe, PMID:23756434

14. Van Moll CC, Schep G, Vreugdenhil A, Savelberg HH, Husson O: Cancer prehabilitation: an opportunity to decrease treatment-related morbidity, increase cancer treatment options, and improve physical and psychological health outcomes. Acta Oncol 2016;55:539-546. DOI:10.3109/0284186X.2015.1127414, PMID:26755191

15. Heywood R, McCarthy AL, Skinner TL: Efficacy of exercise interventions in patients with advanced cancer: a systematic review. Arch Phys Med Rehabil 2018;99:2595-2620. DOI:10.1016/j.apmr.2018.04.008, PMID:29738745

16. Sweegers MG, Altenburg TM, Brug J, May AM, van Vulpen JK, Aaronson NK, Arbane G, Bohus M, Courneya KS, Daley AJ, Galvao DA, Garrod R, Griffith KA, Van Harten WH, Hayes SC, Herrero-Román F, Kersten MJ, Lucia A, McConnachie A, van Mechelen W, Mutrie N, Newton RU, Nollet F, Potthoff K, Schmidt ME, Schmitz KH, Schulz KH, Sonke G, Steindorf K, Stuiver MM, Taaffe DR, Thorsen L, Twisk JW, Velthuis MJ, Wenzel J, Winters-Stone KM, Wiskemann J, Chin A Paw MJ, Buffart LM: Effects and moderators of exercise on muscle strength, muscle function and aerobic fitness in patients with cancer: a meta-analysis of individual patient data. Br J Sports Med 2019;53:812. DOI:10.1136/bjsports-2018-099191, PMID:30181323

17. Nakano J, Hashizume $\mathrm{K}$, Fukushima $\mathrm{T}$, Ueno $\mathrm{K}$, Matsuura E, Ikio Y, Ishii S, Morishita S, Tanaka K, Kusuba Y: Effects of aerobic and resistance exercises on physical symptoms in cancer patients: a meta-analysis. Integr Cancer Ther 2018;17:1048-1058. DOI:10.1177/1534735418807555, PMID:30352523
18. Fukushima T, Nakano J, Hashizume K, Ueno K, Matsuura E, Ikio Y, Ishii S, Morishita S, Tanaka K, Kusuba Y: Effects of aerobic, resistance, and mixed exercises on quality of life in patients with cancer: a systematic review and meta-analysis. Complement Ther Clin Pract 2021;42:101290. DOI:10.1016/j.ctcp.2020.101290, PMID:33360071

19. Mishra SI, Scherer RW, Geigle PM, Berlanstein DR, Topaloglu O, Gotay CC, Snyder C: Exercise interventions on health-related quality of life for cancer survivors. Cochrane Database Syst Rev 2012;8:CD007566. DOI:10.1002/14651858.CD007566. pub2, PMID:22895961

20. Mishra SI, Scherer RW, Snyder C, Geigle PM, Berlanstein DR, Topaloglu O: Exercise interventions on health-related quality of life for people with cancer during active treatment. Cochrane Database Syst Rev 2012;8:CD008465. DOI:10.1002/14651858.CD008465. pub2, PMID:22895974

21. Tsuji T: The front line of cancer rehabilitation in Japan: current status and future issues. J Cancer Rehabil 2019;2:10-17.

22. Hamaguchi T, Okamura H, Nakaya N, Abe K, Abe Y, Umezawa S, Kurihara M, Nakaya K, Yomiya K, Uchitomi Y: Survey of the current status of cancer rehabilitation in Japan. Disabil Rehabil 2008;30:559-564. DOI:10.1080/09638280701377003, PMID:17852319

23. Ikegami N, Yoo BK, Hashimoto H, Matsumoto M, Ogata H, Babazono A, Watanabe R, Shibuya K, Yang BM, Reich MR, Kobayashi Y: Japanese universal health coverage: evolution, achievements, and challenges. Lancet 2011;378:1106-1115. DOI:10.1016/ S0140-6736(11)60828-3, PMID:21885107

24. Silver JK, Stout NL, Fu JB, Pratt-Chapman M, Haylock PJ, Sharma R: The state of cancer rehabilitation in the United States. J Cancer Rehabil 2018;1:1-8. PMID:30882090

25. Lisy K, Denehy L, Chan RJ, Khan F, Piper A, Jefford M: The state of cancer rehabilitation in Australia. J Cancer Rehabil 2018;1:9-13.

26. Kazanjian A, Jones JM, Carlson LE, Chasen M, Bhargava R, Langelier D: Reflections on cancer rehabilitation and survivorship in Canada: observing ten years of evidence informed practice. J Cancer Rehabil 2019;2:18-23. 


\section{APPENDIX 1 JAPANESE VERSION OF THE QUESTIONNAIRE}

\section{がん患者に対する外来リハビリテーションの実態調査}

※このアンケートはがんリハビリテーションの実施状況を，最も把握している方に よるご回答をよろしくお願いいたします。

回答者の職種 : (1)理学療法士 (2)作業療法士 (3)言語聴覚士

(4)リハビリテーション科医

【1】施設の概要についてお答えください。 Q1. 施設の種類をお選びください

1.大学病院 2.がん専門病院 3.-般病院 4.その他

Q2. 拠点病院の指定状況をお選びください

1.都道府県がん診療連携拠点病院 2.特定領域がん診療連携拠点病院

3.地域がん診療連携拠点病院 4.地域がん診療病院 5.その他

Q3. 施設の所在地をお選びください

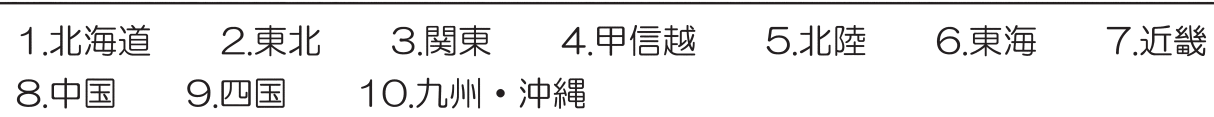

Q4. 施設の病床数をお選びください

1. 600床 2. 601 床

Q5. リハビリテーション専従医の有無についてお選びください

1.有り 2.無し

Q6.セラピスト数をお答えください

\begin{tabular}{lllll} 
1.PT ( ) 名 2. OT ( ) 名 3. ST ( ) 名 \\
\hline
\end{tabular}

Q7.がんリハビリテーション研修修了セラピスト数をお答えください

1.PT ( ) 名 2. OT ( ) 名 3. ST ( ) 名


【2】外来リハビリテーションの実施状況についてお答えください。 Q8. がん患者に対して外来リハビリテーションを実施していますか? (外来リハ開始ががんによる患者、疾患別リハビリテーション料で算定している 場合も実施に含みます)

1.している $\rightarrow$ Q9へお進みください

2. していない $\rightarrow$ Q11へお進みください

【3】がん患者に対して外来リハビリテーションを実施している施設の方はお答え ください。

Q9. がん患者に対する外来リハビリテーションは十分行えていると感じますか? 1.十分行えている 2.不十分である $\rightarrow Q 10 \wedge$

Q10 Q9で不十分と答えた施設の方は，その理由をお答えください。【複数回答可】

1. 外来がんリハの診療報酬が現状で算定できない２.外来がんリハプログラムの教 育不足３.スタッフ/マンパワーの不足４.対象患者はいるがリハ処方がない
5.施設・設備が不十分
6. プログラムの患者のアドヒアランスが得られない

【4】がん患者に対して外来リハビリテーション未実施施設の方はお答えください。 Q11. 貴施設で外来リハを実施していない理由を以下の設問について、該当する数字 O〜3からーつ選んで下さい。

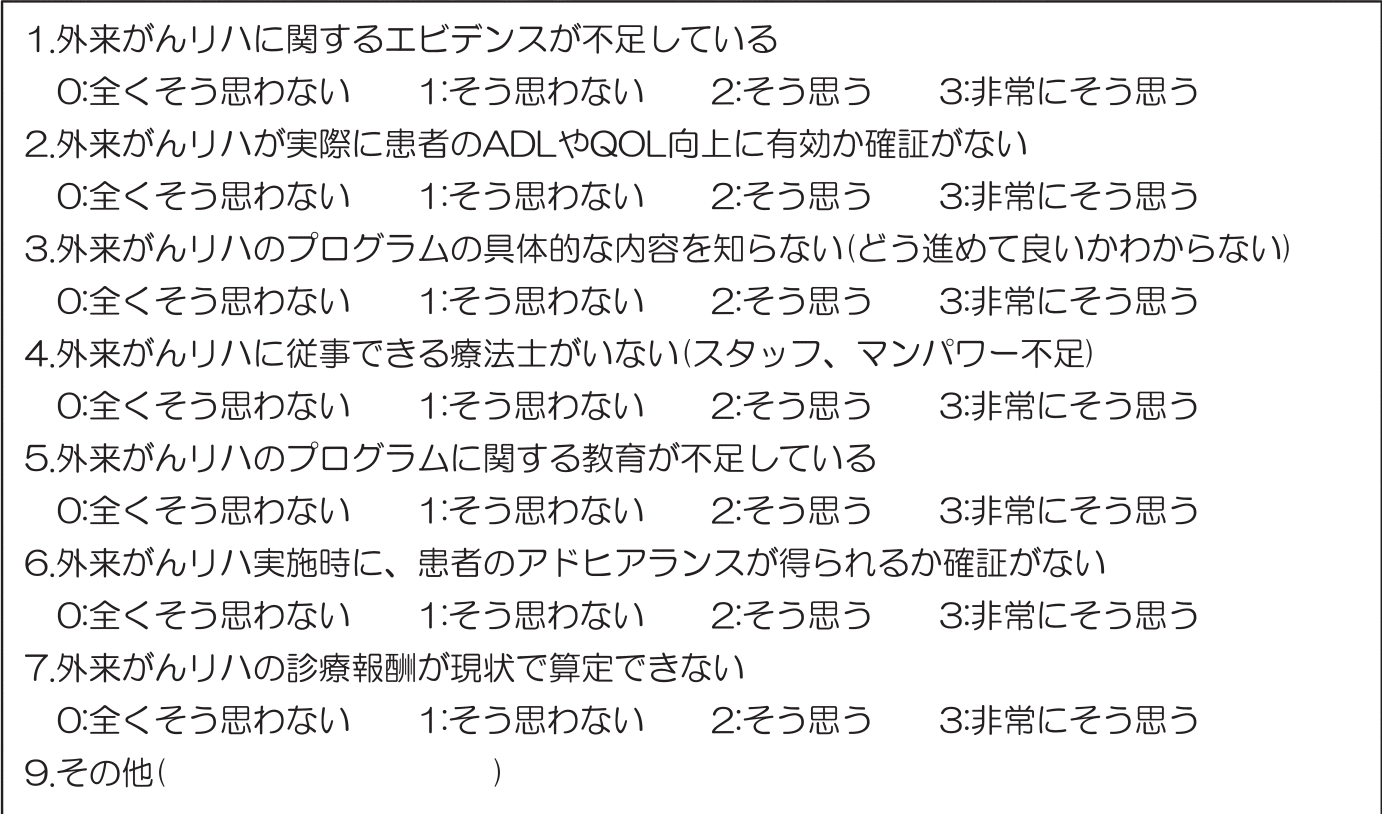

Q12. がん患者外来リハビリテーションの必要性をお答えください

1. ある 2. ない


【5】がん患者に対する地域連携についてお答えください。 Q13. がん患者に対してリハビリテーションが関与した地域連携がありますか?

1. ある $\rightarrow$ Q14へお進みください

2.ない $\rightarrow$ Q15へお進みください

【6】がん患者に対する地域連携を実施している施設はお答えください。 Q14.がん患者に特化した地域連携パス(リハビリテーション関与)がありますか?
1. ある
2.ない

【 7 】がん患者に対する地域連携未実施の施設はお答えください。 Q15. 地域連携が困難な理由をお答えください。【複数回答可】

1.システムが不十分 2.包含医療圏が広域に及ぶ 3.患者ごとの個別性が高い

4.地域連携導入の契機がない５.その他(

)

Q16.がん患者に対する地域連携の必要性についてお答え下さい
1. ある
2. ない

ご多忙のところアンケートにご協力いただき誠にありがとうございました。 